ARTÍCULOS 

FILOLOGÍA CLÁSICA 



\title{
O JOGO DE APARÊNCIAS E DE OPINIÕES NA TRAGÉDIA HELENA DE EURÍPIDES
}

\author{
José ANTONio Alves TORRANO \\ Departamento de Letras Clássicas e Vernáculas \\ da Universidade de São Paulo \\ jtorrano@usp.br
}

\section{RESUMO}

A análise hermenêutica permite-nos ver como, na tragédia Helena de Eurípides, o desenvolvimento temático se dá mediante o jogo de aparências e de opiniões, como o segundo estásimo se integra motivada e perfeitamente a essa tragédia, e como a dialética trágica prepara e integra a cena da epifania do Deus ex machina e os versos finais do coro - comuns a outras quatro tragédias de Eurípides.

Palavras-Chave: tragédia; Helena; Eurípides; Deus ex machina.

\section{RESUMEN}

El análisis hermenéutico nos permite ver cómo, en la Helena de Eurípides, el desarrollo temático tiene lugar mediante el juego de apariencias y de opiniones, cómo el segundo estásimo se integra motivada y perfectamente en esa tragedia, y cómo la dialéctica trágica prepara e integra la escena de la epifanía del Deus ex machina y los versos finales del coro -comunes a otras cuatro tragedias de Eurípides-.

Palabras Clave: tragedia, Helena, Eurípides, Deus ex machina.

${ }^{1}$ Professor doutor titular de Língua e Literatura Grega na Universidade de São Paulo. O presente estudo é parte do trabalho realizado como visitante junto ao Departamento de Filología Clásica da Universidad Nacional de Educación a Distancia (UNED), Madrid, com a bolsa PDE do CNPq no período de 01/12/2009 a 30/06/2010, e com a bolsa Movibilidad de Professores Brasileños da Fundación Carolina, no período de 01/12/2009 a 28/02/2010. 
O prólogo (Hel. 1-163) desta tragédia tem duas partes: o monólogo de Helena e o diálogo entre esta e Teucro. Na primeira parte (Hel. 1-67), a figura de Helena é vista pelo lado direito, como inocente e inteiramente isenta de culpa de todas as acusações que pesam sobre ela; na segunda parte (Hel. 68-163), contrapõe-se o peso das acusações com todo o ódio e horror que elas trazem consigo.

A referência inicial ao rio Nilo e ao rei Proteu situa a ação no Egito, e assim se retomam duas passagens da Odisséia: a narrativa do retorno de Menelau, com o seu trânsito por Egito, onde consulta o Deus marinho Proteu (Odisséia, IV, 349), e a menção da origem egípcia da droga contra dores e mágoas, que Helena oferece e serve a seus hóspedes Telêmaco e Pisístrato no palácio de Menelau (Odisséia, IV, 227-230). No entanto, nesta tragédia, Proteu é um mortal, já falecido, embora tenha desposado uma Deusa, a nereida Psâmate, o que explica o saber mântico de sua filha Teônoe, que terá importância decisiva no desenvolvimento do drama (Hel. 1-15).

Ao apresentar-se, Helena nomeia Esparta por pátria e Tindáreo por pai, e como «uma lenda» (lógos tis, Hel. 18), «se a lenda é clara» (ei saphès hoûtos lógos, H. 21), que sua mãe Leda tenha sido fecundada em união com Zeus Pai, na enganosa forma de um cisne a fugir de uma águia; nomeia-se, então, a si mesma e dispõe-se a falar de que males tem sofrido.

Seus males têm origem, implicitamente, nessa alegada incerteza da paternidade divina e, explicitamente, no julgamento de Páris da beleza das três Deusas: «Hera, Cípris e a filha de Zeus virgem» (Hel. 25). Hera, irmã e esposa de Zeus, tem por domínio o casamento enquanto instituição social e o patrimônio familiar; Afrodite, dita «Cípris», a beleza, a sedução e os jogos amorosos; Atena, dita «a filha de Zeus virgem», a inteligência estratégica e, em geral, o saber fazer. Cípris vence o julgamento ao premiar, por sua vitória, o juiz, com a beleza de Helena. Quando Helena se refere à sua própria beleza (toumòn dè kállos, Hel. 27) com a ressalva «se o infortúnio é belo» (ei kalòn tò dystykhés, Hel. 27), ressalta-se o vínculo, tradicional na concepção grega, entre beleza e bem, beleza e verdade, pelo que o belo é belo quando também é bom. O mitologema do julgamento de Páris tem um profundo sentido teológico: a cada Deus concernem as atribuições que lhe são próprias, o que se diz as suas «honras» (timaí, cf. Hesíodo, Teogonia, 201, 414, 426 \&c.). Tal como na teoria platônica da comunidade dos gêneros (Platão, Sofista, 250ss.) cada gênero se diz «o mesmo» com relação a si mesmo, e «outro», com relação a todos os outros, assim também nesse mitologema do julgamento, a cada Deus concerne o seu próprio interesse, com exclusão do que importa aos demais Deuses. A escolha e o juízo de Páris nesse julgamento determinam a sorte e o destino do próprio Páris, mas também repercutem e reverbera no que se situa no âmbito de Afrodite, avassalando assim a beleza e a vida de Helena.

Nesse conflito de interesses divinos, que o juízo do mortal Páris decide, mas não resolve, Hera, preterida, tenta anular a vitória de Afrodite, criando uma «imagem animada, composta no céu» (eídolon émpnoun ouranô̂ xunteis'ápo, Hel. 34). Ao dar a Páris essa «imagem animada» em vez da verdadeira Helena, sobrepõe ao conflito divino um jogo enganoso de «vã opinião» (keinèn dókesin, Hel. 36), em que Páris crê ter Helena, mas não tem (e neste «ter», ékhein, vige a acepção sexual de «possuir», Hel. 35), e o jogo de enganos se amplia ao envolver gregos e troianos em guerra. 
Hermes, o Deus cujo âmbito se manifesta na comunicação e na solidão dos caminhos, participa desse jogo envolvente de opinião e de aparência, ao seqüestrar - ele, o Deus Hermes, e não Páris - furtivamente Helena e conduzi-la em segurança ao palácio de Proteu, rei do Egito, considerado o mais prudente de todos os mortais (Hel. 44-49).

Hera pode assim resolver o conflito das três Deusas dissolvendo-o nesse jogo - mortífero para os mortais - de crenças e de aparências, e ao resolvê-lo assim está em verdade a serviço de duplos desígnios de Zeus: «aliviar / a terra mãe da multidão de mortais / e celebrar o mais forte da Grécia» (Hel. 39-41). «O mais forte da Grécia», tòn krátiston Helládos (Hel, 41), é, sem dúvida, Aquiles, cuja glória se deve à sua participação na guerra de Tróia (cf. Ilíada, 1.244).

Hermes não só preserva a integridade física e moral de Helena, ao conduzi-la e pô-la sob a guarda do egípcio Proteu, mas ainda lhe revela a condição de seu retorno à pátria Esparta e ao convívio do marido, a saber: não servir leito algum (Hel. 59).

Quando morre o seu protetor, e o filho Teoclímeno, que o sucede no trono, cobiça desposá-la, Helena se refugia no túmulo do antigo rei, suplicando-lhe asilo e proteção. O túmulo, pois, deve estar situado diante do palácio real, integrando o cenário desta tragédia (Hel. 60-65). Nesta cena inicial, o valoroso empenho de Helena na preservação da castidade por amor do marido e da reconstituição de suas núpcias faz dela um êmulo de Penélope como paradigma mítico da prudência e da fidelidade conjugal.

Se ela tem na Grécia o nome inglório, conspurcado por terrível jogo de aparências e de ilusões, resta-lhe, no entanto, a virtude de lutar pela castidade e integridade físicas, em nome de seu amor pelo marido e pelas núpcias, que o jogo promovido pelos Deuses arrebatou (Hel. 66-67).

Na segunda parte do prólogo (Hel. 68-163), Helena é vista pelo lado esquerdo, acusada de adultério, abandono do lar, deserção da pátria, motivo da guerra, causa de inúmeros sofrimentos, entre os quais o suicídio de sua mãe e de seus dois irmãos, por não suportarem o opróbrio suscitado pela conduta que lhe atribuem, e causa do massacre da multidão de gregos e de troianos.

Circunscrita ao túmulo do falecido rei como suplicante, sem poder abandoná-lo sob a ameaça de núpcias forçadas com o rei atual, Helena participa da segunda cena, marcada pela entrada de Teucro, o arqueiro irmão bastardo de Ájax, que sobrevive a este e à guerra. Num relance, antes de avistar Helena, o olhar de Teucro fixa o opulento palácio real, comparável à própria Riqueza em si mesma (Ploútoi, Hel. 69); esta comparação traz consigo, na perspectiva do imaginário grego, duas alusões, ambas sinistras: o nome grego de «Riqueza», Ploutos, ao lembrar Plutão (Ploúton, eufemismo para Hades, o Deus dos mortos, cujo reino é rico por sua irrestrita hospitalidade), sugere o risco de morte que aí correm os gregos; além disso, a grande riqueza é vista na tragédia como a ocasião de hýbris («transgressão) e de áte («erronia» ou «ruína»), traços que, aliás, marcam o comportamento do rei Teoclímeno.

Ao avistar Helena, Teucro a toma por uma cruel imagem da odiosa mulher destruidora de sua vida e dos gregos, com tão forte repulsa que só a condição de hóspede em terra alheia o impede de matá-la por ostentar tal semelhança (Hel. 72-77). Tão súbito quão arraigado se instaura o duplo equívoco entre Helena e sua imagem por um lado e, por outro, entre a causa da guerra e sua primeira vítima, Helena. A insistência de Teucro na visão como fonte da verdade do seu saber só revela quão arraigado é o seu equívoco («que visão vi?», «vejo», Hel. 72). 
Helena faz clara distinção entre si mesma e aquela (imagem) causadora dos infortúnios sofridos; Teucro compreende que não tem diante de si a causadora mesma de seus infortúnios, mas alguém semelhante a ela, e desculpa-se, dando a Helena a oportunidade de prosseguir e colher informações ( $\mathrm{Hel}$. 78-82).

$\mathrm{Na}$ esticomitia (Hel. 83-141) primeiro pergunta a respeito de seu próprio interlocutor (Hel. 83-106); depois, sobre a devastação de Tróia e a duração do assédio (Hel. 107-114); a notícia da captura da «mulher de Esparta», arrastada pelos cabelos à maneira das cativas troianas, instiga a indagar e verificar o grau e a persistência da ilusão e da convicção criada pela imagem (Hel. 115-122), quando a força da convicção se torna velada ironia, cuja latência ainda mais a fortalece: «vi mesmo com os olhos, a mente vê» (Hel. 122); Helena tem então notícia do suposto naufrágio de Menelau (Hel. 123-132, cf. Ésquilo, Agamêmnon, 650-675) e do suicídio de Leda motivado pela má fama da filha (Hel. 133-136) e ainda da sorte ambígua de seus irmãos, que ora se dizem transformados em astros e Deuses, ora imolados pelo opróbrio da irmã (137-142).

Embora desejoso de consultar a profetisa Teônoe sobre a navegação a Chipre, onde Apolo lhe vaticinou fundar uma nova Salamina, Teucro é dissuadido por Helena, que o alerta de que o rei dessa terra põe à morte quantos forasteiros gregos captura, aconselhando-o a interrogar antes a viagem mesma (Hel. 143-157). Em retribuição às boas palavras salvadoras, Teucro distingue entre Helena, que os destruiu, e esta que, por mais semelhante àquela, no entanto os salva, imprecando contra aquela, e bendizendo a esta; $\mathrm{e}$ parte, deixando à verdadeira Helena a dor e a lástima do luto por seus mortos e por seu marido supostamente náufrago e morto.

O párodo (Hel. 164-251) amebeu se compõe da interlocução entre Helena e o coro de cativas gregas, que acode aos queixumes. Ante a extensão de suas dores e de seu luto, Helena se pergunta com que cantos lhes dar expressão (Hel. 164-166).

Na primeira estrofe (Hel. 167-178), Helena invoca e pede às Sereias, sinistras e mortíferas cantoras, que deem ressonância a seus cantos, para que possa enviar «graças» (kháritas, Hel. 175) à cruel Perséfone, esposa de Hades, Deusa dos ínferos e dos finados. A antífrase que designa «graças» ao desgraçado pranto pelos mortos (cf. Ésquilo, Coéforas, 320) ainda se reitera no aposto em que o pranto fúnebre se diz «peã» - o canto exultante de celebração ao Deus Apolo, à vida e à vitória (cf. Ésquilo, Agamêmnon, 645, Coéforas, 151).

Na primeira antístrofe (Hel. 179-190), apresenta-se o coro: as cativas gregas, enquanto lavavam e secavam os mantos, não seus, mas da nobreza (o que a cor indica, pois são «purpúreos», phoínikas, Hel. 181), ouviram o clamor de uma voz chorosa, comparável à de uma ninfa Náiade perseguida por Pã desejoso de amor, e acodem, solidárias. A comparação do pranto de Helena com o clamor da ninfa assediada pela luxúria de Pã recorda a condição de Helena que, forçada pelo rei Teoclímeno a núpcias indesejadas, se refugia no túmulo de seu antigo protetor a suplicar por asilo.

Na segunda estrofe (Hel. 191-210), completa-se a identificação do coro: a interpelação de Helena «ó caça do remo bárbaro» (Hel. 191) as descreve como seqüestradas por piratas estrangeiros e vendidas como escravas. Helena, então, lhes comunica as notícias dos novos infortúnios, recebidas de Teucro: o incêndio de Tróia devastada, o suicídio de Leda, abatida pela infâmia da filha, a morte de Menelau em naufrágio e a de seus irmãos gêmeos. 
Na segunda antístrofe (Hel. 211-228), o coro lastima o Nume deplorável, a sorte e a vida difícil que coube à filha que Zeus, em forma de cisne, gerou, sobranceiro no céu; lastima as mortes da mãe e dos irmãos; lastima o exílio e a infâmia, a morte do marido no mar e a consequente perda de esperanças de retorno à antiga felicidade na terra pátria.

No epodo (Hel. 229-251), Helena rememora as origens de seus males: por um lado, a viagem de Páris, acompanhado de Afrodite, a Esparta, para fazê-la sua esposa; e por outro lado, o envio do Deus Hermes pela Deusa Hera a Esparta, para conduzi-la ao Egito, quando ela colhia rosas para adornar o templo da Deusa Atena, «a de brônzea casa»; e por fim lastima a infundada difamação de seu nome em Tróia, junto ao rio Simoente.

O primeiro episódio (Hel. 253-514) se compõe de quatro cenas: na primeira cena (Hel. 253-383) Helena lamenta a sua sorte, acolhe o conselho, que o corifeu lhe dá, de consultar a profetisa Teônoe, e dispõe-se a deixar o asilo tumular para visitar a profetisa, no que é acompanhada pelo coro, que assim deixa a orquestra; na segunda cena ( $\mathrm{Hel}$. 386-436), Menelau entra a sós e se apresenta; na terceira cena (Hel. 437-482), Menelau dialoga com a velha serva do palácio real; e na quarta cena (Hel. 483-514), Menelau de novo a sós reflete num monólogo.

Nessa primeira cena do primeiro episódio, inicialmente, em sua longa fala, $(\mathrm{Hel}$. 255-305), Helena não só reitera a dúvida de sua filiação divina (phasín, Hel. 259, cf. lógos tis hos, Hel. 17, ei saphès hoûtos logos, Hel. 21), mas ainda usa pejorativamente o termo «prodígio» (terás, Hel. 260) para descrever tanto sua alegada origem divina quanto o caráter extraordinário de seus infortúnios. A incredulidade sobre sua filiação a Zeus repercute o sentimento de derrelição e abandono. Quando se perdem o lar e a família, é manifesto o desfavor de Hera (Hel. 261). A beleza de Helena perde para ela todo valor, anulada, quando a rumorosa infâmia rompe os vínculos e as referências da pátria; no exílio e no desamparo, Helena prefere ver-se feia em vez da bela, se ao extinguir a sua bela imagem extinguisse também a infundada infâmia (Hel. 261-266). Pelas notícias recebidas, os infortúnios de Helena se multiplicam até o insuportável; ela os enumera: a infâmia sem razão que a justifique (Hel. 270-272); o exílio em terra bárbara, onde todos, menos um, são escravos (Hel. 273-276); a morte do marido e, com ela, a perda de toda esperança de libertação dos seus males (Hel. 277-279); a morte da mãe e a injusta acusação que lhe pesa por essa morte (Hel. 280-281); o indefinido adiamento das núpcias da filha, substituídas por «grisalho celibato», devido ao opróbrio atribuído à mãe (Hel. 282-283); a morte dos Dióscoros, pelo mesmo motivo (Hel. 284-285). Diante desses infortúnios produzidos por um opróbrio que injustamente lhe é atribuído, Helena se diz morta, pelos fatos, mas não por seus atos (Hel. 285-286). Essa morte moral se configura também como a morte social, que a desaparição no marido em naufrágio torna completa e irreversível, consumando assim o elenco dos males: ainda que banida e excluída de sua pátria como traidora, poderia ainda se fazer reconhecida por ele, mediante sinais compartilhados por ambos, mas essa última esperança se perde com a desaparição dele (Hel. 287-292). Considerando inaceitável a alternativa de viver no exílio como mulher de bárbaro, não lhe resta mais que escolher o melhor meio de suicídio, a forca ou a lâmina. Ao avaliar a conveniência e inconveniência, para si mesma, de cada um desses instrumentos fatais, Helena reflete que a mesma beleza - estimada pelas outras mulheres como boa sorte - a destrói ( Hel. 293$305)$. 
Ante o impasse, o corifeu põe em dúvida a veracidade e clareza das notícias recebidas de um forasteiro desconhecido, e aconselha que se consulte Teônoe, a onisciente filha da Nereida Psâmate, se Menelau vive ou está morto, oferecendo-se solidariamente a acompanhá-la nessa consulta (Hel. 306-329).

Acolhido o conselho, o temor do que o vaticínio possa revelar retém ainda os passos de Helena (Hel. 330-345). Apesar de encorajada pelo corifeu (Hel. 346-347), ela rememora o juramento de, se confirmada a morte do marido, enforcar-se ou imolar-se, declarando que seria um sacrifício às três Deusas e ao Priâmida Páris. A demorada redundância que dá ênfase à descrição do suicídio jurado, a alusão elíptica às três Deusas (trizýgois Theaîs, Hel. 357), que se subentendem Hera, Afrodite e Atena, mas que a elipse permite ainda identificar com as Deusas da partilha «Partes» (Moîrai), e a associação das Deusas a um mortal, Páris, como destinatários do sacrifício, conferem à fala de Helena a sombria ressonância de um tétrico sarcasmo (Hel. 348-359). O corifeu faz, então, uma prece apotropaica (Hel. 360-361).

Helena lastima que os seus «dons de Cípris» (dôra Kýpridos, Hel. 364) tenham produzido tantas mortes, dores, prantos e lutos em Tróia (Hel. 363-369) e na Grécia (Hel. 370-374). Por fim, compara o próprio infortúnio aos de duas figuras femininas legendárias, Calisto e a filha de Mérops, as quais como ela sofreram por causa da própria beleza: Calisto, amada por Zeus e transformada em ursa, e a anônima filha de Mérops, detestada por Ártemis e transformada em corça. Nessa comparação, mostra o quanto o seu sofrimento - atual e sem fim previsível - excede o dessas mulheres, pois o delas teve um desfecho na transmutação em forma animal e limitou-se somente a elas, enquanto o interminável infortúnio de Helena a ultrapassa e atinge multidões de longínquos troianos e de seus compatriotas (Hel. 375-385).

Na segunda cena do primeiro episódio (Hel. 386-434), o monólogo de Menelau se estrutura como um segundo prólogo.

A invocação inicial a Pélops, lembrado pela vitória sobre Enômao na competição de quadrigas em Pisa, e pelo banquete compartilhado com os Deuses, somente o interpela como testemunha de um impossível desejo de que esse magnífico antepassado tivesse morrido sem deixar descendentes, sem que tivesse gerado Atreu, pai de Agamêmnon e do próprio Menelau. Essa invocação e essa formulação desse desejo - inexeqüível porque sua realização implicaria a anulação de acontecimentos já pretéritos - não somente exprime o desejo de Menelau de ele mesmo não existir, mas também o contraste entre os seus gloriosos antepassados e suas presentes circunstâncias de penúria e miséria (Hel. 386-392). Apresenta-se, então, como o condutor do maior exército naval de voluntários contra Tróia, apenas para contrastar a magnificência dessa esquadra com o saldo de mortos e de supérstites testemunhas de tantos mortos (Hel. 393-399). Desde a conquista de Tróia, as errâncias no mar e os ventos adversos o afastaram do almejado retorno à pátria, e por fim o naufrágio o lança às costas de uma terra desconhecida, salvo por inesperada sorte com Helena, sem alimentos, nem vestes, coberto com restos de seu navio, aflito e constrangido pela carência e penúria (Hel. 400-424). Constata e reitera a súbita novidade e desconforto da reviravolta da fortuna. (Hel. 417-419, 423-424). Tendo ocultado numa gruta a mulher a quem atribui o princípio de seus males, e tendo obrigado os seus companheiros restantes a vigiá-la, à procura do que lhes possa ser útil, depara com o palácio, diante do qual antes Teucro sem reconhecer encontrara Helena, e chama por quem possa anunciá-lo aos donos da casa (Hel. 424-436). 
Na terceira cena do primeiro episódio (Hel. 437-482), o diálogo de Menelau com a velha serva do palácio real expõe e ressalta a carência, a miséria e a miserabilidade de quem antes poderoso condutor de exército agora não calou que seu primeiro e maior desejo é o de não ter nascido. A meu ver, os traços cômicos desta cena - em que o grande senhor da guerra é barrado e ameaçado por velha escrava enfurecida - visam reforçar o revés da fortuna e o contraste entre as circunstâncias presentes e o glorioso passado.

A velha dá a Menelau importantes informações: primeiro que por ser grego não é bem-vindo, mas corre risco de vida (Hel. 439-440); depois, que chegou ao Egito, à casa do rei Proteu (Hel. 460); em seguida, que o túmulo, diante do palácio, é desse rei, e o seu filho, e sucessor no trono, é hostil aos gregos (Hel. 466-468); e por fim, que «Helena, filha de Zeus, está nesta casa» (Hel.470), explicando ainda que a Tindárida chegou de Esparta antes de os gregos irem para Tróia (Hel. 472-475), e concluindo com a reafirmação de que se o dono da casa o detiver, a morte será o dom de hospitalidade (Hel. 479-480).

$\mathrm{Na}$ abertura desta cena, os traços cômicos se fundem com o elemento trágico mediante a reminiscência do épico: esse encontro de Menelau, náufrago, nu e perdido, com uma velha escrava furibunda, que o repele e ameaça, subverte o encontro de Odisseu em iguais circunstâncias com uma jovem princesa, formosa e gentil, que o acolhe e lhe dá abrigo. No final desta cena, a reminiscência do épico depura e reforça o elemento trágico: o dom de hospitalidade que se oferece a Menelau é o mesmo que o ciclope Polifemo promete a Odisseu - a morte, sendo o último a ser morto (Hel. 449 e 480; cf. Odisséia IX, 369-370).

Na quarta e última cena do primeiro episódio (Hel. 483-514), num monólogo, Menelau de novo a sós reflete sobre o duplo problema com que se depara, o de que haja duas Helenas, ambas filhas de Zeus e de Tindáreo e vindas de Esparta; e o de que o rei dessa terra ponha à morte todo grego que prende. Resolve o primeiro com o recurso à homonímia: «muitos na vasta terra / têm os mesmos nomes, cidade e cidade / mulher e mulher» (Hel. 497-499), e o segundo, não só com a confiança de que o seu famoso nome possa favorecê-lo (Hel. 501-502), mas ainda com o recurso à astúcia de esconder-se e de aguardar a oportunidade de intervir e interpelar, se for o caso (Hel. 505-507). Nenhuma dessas duas soluções previamente propostas se verificará eficaz ou suficiente, mas a sua atitude de não fugir e de enfrentar revela a têmpera do senhor da guerra.

No epipárodo (Hel. 515-527), um canto astrófico anuncia a revelação por Teônoe de que Menelau está vivo e percorre o mar sem ter logrado o retorno à pátria desde Tróia.

O segundo episódio ( $\mathrm{Hel}$. 528-1106) se compõe de seis cenas: na primeira cena ( $\mathrm{Hel}$. 528-596), temos Helena e Menelau; na segunda cena (Hel. 597-760), os mesmos e o velho servo de Menelau; na terceira cena (Hel. 761-856), Helena e Menelau de novo sós; na quarta cena (Hel. 857-872), os mesmos e a adivinha Teônoe junto a duas personagens mudas; na quinta cena (Hel. 873-1031), Teônoe, Helena e Menelau; e na sexta cena (Hel. 1032-1106), Helena e Menelau outra vez sós.

Na primeira cena (Hel. 528-596) do segundo episódio, Helena retorna da consulta à adivinha Teônoe, reconfortada com a revelação de que Menelau está vivo, salvo de um naufrágio e próximo de reencontrá-la. Esse regozijo é bruscamente interrompido pela súbita aparição de um homem com aspecto selvagem e vestes informes, no seu caminho para o asilo no sepulcro do antigo rei. Na esticomitia (Hel. 553-593), Helena reconhece 
Menelau, sem que ele ainda possa reconhecê-la, o que contraria o padrão de outras célebres cenas de reconhecimento, nas quais a identidade do recém-chegado é problemática, não a de quem o recebe (cf. Odisséia, Ésquilo - Coéforas, Eurípides - Electra). Ainda que a visão de Helena num primeiro momento lhe cause estupor e silêncio (Hel. 549), a convicção de que a imagem animada seja a verdadeira Helena impede Menelau de reconhecê-la. Quando ela se declara sua esposa, ele invoca a Deusa noturna e subterrânea Hécate, com a súplica de que lhe envie «gentis visões» (phasmat eumenê, Hel. 569); apesar de ter reafirmado a extrema semelhança física dessa visão com Helena, o seu caráter perturbador tem algo sombrio e infernal, o que Helena refuta com a constatação de que não lhe surgiu à noite, qual «serva de Enódia» (Hel. 570), Deusa das encruzilhadas e de sepulturas à beira do caminho, ainda que efetivamente se encontrem diante da sepultura em que Helena buscava asilo e proteção. Mas, suposto que não seja uma visão espectral, Menelau protesta que não é marido de duas mulheres, convicto de que a sua esposa está na gruta onde a guardou; nem o apelo à fidedignidade, clareza e verdade da visão de seus olhos pode demovê-lo da convicção de que lutou e sofreu em Tróia por ter outra mulher. Soa-lhe como paradoxos a explicação, dada por Helena, de que ela própria não esteve em Tróia, mas que a Deusa Hera fez do fulgor celeste uma imagem animada para que Páris não a levasse nem tivesse. Somados à descrença da incredulidade os seus infortúnios, ele lhe diz adeus, apesar de Helena protestar que o perdia para um «falso leito» (kén ... lékhe, Hel. 590), após tê-lo encontrado, e que, ao perdê-lo, perdia também o retorno à Grécia e à pátria.

Na segunda cena (Hel. 597-757) do segundo episódio, intervém o velho, de que depois se saberá que servia na casa paterna de Helena ( $\mathrm{Hel}$. 720-725) e que lutou com Menelau em Tróia (Hel. 734-735). O seu relato a respeito (da imagem) de Helena (Hel. 605615), que dará a Menelau condições de reconhecê-la (Hel. 622-624), ressalta, entretanto, o limite estreito de sua compreensão dos fatos mesmos que relata: não compreende que quem ascende ao céu é a imagem etérea e, feito o relato, ao ver a Helena mesma, pensa ter sido ludibriado por ela e lhe atribui «corpo alado» (hypópteron / démas, Hel. 618619). Ainda que não lhes alcance o sentido, o velho reproduz as palavras da imagem com tal exatidão que permite a Menelau ter uma percepção mais ampla e mais clara dos fatos e assim reconhecer Helena. A similitude entre a imagem e Helena não se esgota na aparência física: a imagem - segundo o relato do velho - manifesta comiseração por gregos e troianos, sente-se responsável por suas mortes, atribui às artes de Hera a ilusão enganadora de Páris e causadora da guerra, protesta a inocência de Helena e deplora sua infundada e injusta infâmia, reiterando e ecoando assim as palavras e sentimentos da própria Helena.

Ao reconhecimento mútuo segue o diálogo (Hel. 625-697) dos cônjuges jubilosos de seu reencontro, o gozo do prazer presente então lhes parece suplantar o infortúnio pretérito (Hel. 641-659). No entanto, impõe-se a necessidade de indagar e saber o que os separou, e Menelau, para obter resposta à sua pergunta (Hel. 660), deve reiterá-la, reafirmando que se pode ouvir o que se passou, por serem dons de Numes (dôra Daimónon, Hel. 663) e por ser «doce ouvir as dores» (Hel. 665). Helena, encorajada assim a enfrentar os «amargos poderes», «amarga fala» e o abominável (Hel. 661-664), começa por professar inocência (Hel. 666-668) e descreve a ação dos Deuses Hermes e Hera, o julgamento de Páris e o ardil de Hera, e ainda os infortúnios familiares: além 
do seu lar desfeito, a sua mãe morta e a sua filha inupta por sua infundada e injusta infâmia (Hel. 670-690).

O velho servidor, que testemunha o efusivo reencontro do casal sem uma clara compreensão do que está acontecendo, intervém pedindo explicações a Menelau ( $\mathrm{Hel}$. 700-703), que o atende, solícito e sucinto (Hel. 704-710). O velho, então, faz uma reflexão sobre o caráter imperscrutável dos desígnios divinos e a inelutável instabilidade da sorte, com o que explica a presente situação de seus amos (Hel. 711-719), assevera que Helena não desonrou nem ao pai Tindáreo nem aos irmãos Dióscoros (Hel. 720-721), renova as bênçãos nupciais do casal reunido, recorda que participou dos festejos das núpcias (Hel. 722-725), e explica o que considera ser a nobreza de espírito em sua condição de servo, a saber, a solidariedade com os amos. Esse discurso do velho configura e demarca o ponto de vista pragmático e utilitário cuja perspectiva e alcance delimitam também o seu discurso seguinte, no qual faz severa crítica aos adivinhos, e desde já previamente condiciona e restringe essa crítica. Menelau ordena ao velho que transmita notícias e instruções a seus companheiros (Hel. 734-743). Antes de retirar-se, o velho, como num desabafo, critica os adivinhos e as artes divinatórias, exemplificando com a mântica do fogo da pira e com a dos auspícios, nomeando Calcas e Heleno (Calcas era o adivinho do exército grego em Tróia, e Heleno, filho do rei troiano Príamo), alegando que não alertaram que «os seus morriam por nuvem» (Hel. 750); admite o contra-argumento de que talvez «o Deus não quisesse» (Hel. 752), e conclui que se deve prescindir dos adivinhos, confiando-se unicamente nos sacrifícios e nas preces aos Deuses, bem como no saber e na prudência (Hel. 744-757). Ora, ainda que as duras críticas aos adivinhos remontem à Ilíada e perpassem toda a literatura grega, a adivinhação, seja ela baseada em um saber mântico, ou em um santuário oracular, seja ainda baseada em uma intuição própria, é uma instituição fulcral do pensamento e da piedade gregos arcaicos, e permanece um dos valores centrais das tragédias do período clássico. A adivinhação se confunde com a hermenêutica dos sinais divinos e assim é parte integrante da comunicação com os Deuses. No entanto, não se pode dizer que o discurso do velho contra os adivinhos - secundado e apoiado pelo coro ( $\mathrm{Hel}$. 758-780) - não seja verdadeiro: esse discurso tem o grau de verdade que lhe é próprio, dado e delimitado pelo ponto de vista do velho servo e dos que - como o coro - dele compartilham. A verdade desse discurso, bem como dos discursos anteriores dessa personagem, se circunscreve a um ponto de vista curto e corriqueiro, que não revela nenhuma afinidade especial com nenhum dos Deuses; a afinidade com (algum de) os Deuses é decisiva para que se estabeleça e se funde a verdade da comunicação divina e da interpretação dos sinais divinos. Nesse sentido, o grau de verdade dessa severa crítica aos adivinhos já está prefigurado no anterior relato da desaparição (da imagem etérea) de Helena: tanto nessa crítica quanto nesse relato, o falante mesmo desconhecia o sentido mais amplo e mais verdadeiro das figuras descritas em sua própria fala, ainda que as descrevesse com tal exatidão e veracidade de modo a permitir que uma outra verdade maior de sua mesma fala se revelasse a um outro ponto de vista mais amplo e mais abrangente. Além disso, essa última fala do velho servidor prepara por contraste e assinala um dos extremos do leque das possibilidades abertas pela referência à figura divina da profetisa Teônoe, de quem a seguir se tratará.

Na terceira cena (Hel. 761-856) do segundo episódio, Helena e Menelau, outra vez a sós, conversam primeiro sobre as errâncias de Menelau desde a tomada de Tróia (Hel. 
641-778), e depois, na esticomitia (Hel. 770-841), sobre os perigos que ameaçam a cada um dos dois na presente situação (Hel. 779-812) e sobre as possibilidades de escaparem ao impasse e à morte iminente (Hel. 813-841). O exame do impasse aponta duas saídas possíveis: uma esperança de salvação residiria é na tentativa de persuadir a onisciente profetisa Teônoe a não denunciar a presença de Menelau ao rei Teoclímeno, seu irmão; e a outra saída repousaria no pacto de morte, firmado pelo casal e previsto num anterior juramento de Helena (cf. Hel. 348-359). A integridade e fidelidade conjugal de Helena, configuradas pela variante mítica desta tragédia de Eurípides, têm sua contrapartida na intrepidez e bravura de um Menelau inteiramente devotado à memória gloriosa dos companheiros mortos em combate e dos inimigos que, por tê-los vencido, igualmente lhe cabe honrar (cf. Hel. 845-849).

Na quarta cena (Hel. 857-872) do segundo episódio, Helena em desespero entre queixumes anuncia a entrada da profetisa Teônoe, constando a inutilidade da evasão de Menelau diante da onisciência divinatória e a reincidência do perigo em terra bárbara (Hel. 857-864). Em contraste com a angústia de Helena, Teônoe tem uma entrada magnificente, precedida de duas servas às quais instrui como proceder às purificações rituais: uma, com o brilho do turíbulo aceso, deve defumar o céu, para que o vento seja puro, e a outra, com a chama da tocha, deve purificar o caminho à frente, precavendo-se de eventuais conspurcações; e depois, ambas as servas devem restituir a chama de Hefesto ao palácio. Cumpridas as ordens, as servas saem.

Na quinta cena (Hel. 873-1031) do segundo episódio, Teônoe se dirige a Helena, tendo por testemunhas de suas palavras unicamente o coro das cativas gregas e Menelau. Primeiro indaga pela realização de seus vaticínios, e - como se mostrasse a incontestável efetividade de seus poderes - responde ela mesma, não somente com a identificação de Menelau, mas ainda com a menção do naufrágio e da desaparição da imagem (Hel. 873-875); depois, aponta a incerteza de Menelau quanto ao seu retorno à pátria (Hel. 877, o que Helena deixara de perguntar ao consultá-la, cf. Hel. 535-537), e revela que isso se decidirá nesse mesmo dia com a decisão de uma rixa entre Deuses em reunião perante Zeus, pois Hera e Afrodite agora se defrontam com interesses mudados, mas ainda contrários: Hera quer o retorno do casal à pátria, para mostrar à Grécia a falsidade do dom de Afrodite (no caso, as núpcias de Páris), mas Afrodite quer impedir o retorno, porque isso exporia a inutilidade de seu dom a Páris, com o que comprou a beleza no certame das três Deusas (Hel. 877-886). Por fim, a profetisa declara que o desenlace dependerá de sua própria atitude, se denunciar ou se ocultar a presença de Menelau ao rei Teoclímeno (Hel. 887-890).

No pensamento mítico, pode haver uma concomitância de causas diversas e independentes, concorrentes na efetivação de um mesmo acontecimento. Assim o retorno de Menelau à pátria depende de diversas instâncias operantes em planos diversos, a saber: o resultado da rixa entre Hera e Afrodite, reunidas perante Zeus, a opção da profetisa entre denunciar ou ocultar Menelau, e o desempenho do próprio Menelau em sua luta por se salvar.

Se, com A.M. Dale², aceitamos a autenticidade dos versos Hel. 892-893, a profetisa oscila entre a sua própria segurança, que estaria comprometida se não denunciasse Me-

\footnotetext{
${ }^{2}$ A.M. Dale - Euripides Helen, Bristol Classical, 2004, p. 126.
} 
nelau, e o dever de justiça perante o hóspede e perante a memória do pai morto. A inicial hesitação da profetisa em incorrer em risco de vida por um forasteiro torna mais urgente e decisiva a súplica de Helena, duplicada por argumento de Menelau.

O ritual da súplica, amplificado pelo gesto de prostrar-se ou sentar-se e tocar ou abraçar os joelhos de quem se interpela até que este conceda o que se pede, inscreve o suplicante no âmbito de Zeus Hikésios («Suplicante») e o torna inviolável, o que confere à súplica um poder coativo, respeitadas as injunções da piedade.

Deixando o asilo do sepulcro de seu antigo protetor, e sentando-se em súplica diante de Teônoe, Helena pede-lhe que não diga a seu irmão que Menelau chegou, apelando primeiro ao sentimento de justiça e à piedade filial (Hel. 898-923), depois mostrando que, ao salvar-lhe o marido, salva-lhe também a vida e a honra, com resgate dos bens por ora perdidos (Hel. 924-938), e por fim, apelando de novo à piedade filial, agora descrita como imitação do caráter nobre e justo do pai (Hel. 939-943).

Menelau nega-se a suplicar, alegando que o gesto aviltaria a memória de Tróia ( $\mathrm{Hel}$. 947-953). Em vez disso, dirige-se a Teônoe, apelando, como Helena, ao sentimento de honra e de justiça (Hel.954-958). Além disso, prostrado sobre o sepulcro de Proteu, invoca o morto e cobra-lhe a devolução da esposa, cuja guarda lhe fora confiada, esperando assim forçar Teônoe a devolvê-la, para evitar a má fama do morto outrora glorioso (Hel. 959-968). Depois, invoca Hades, o Deus dos finados, lembrando-lhe os muitos guerreiros que, por Helena (como em paga por seu resgate), matou com sua espada, e pedindo-lhe que, ou os restitua à vida, ou obrigue Teônoe a mostrar-se mais justa que o pai morto e devolver-lhe a esposa (Hel. 969-974). Em seguida, declara que se obrigou por juramentos a lutar pela esposa contra o rei Teoclímeno até matá-lo ou morrer. Se o rei se negar a enfrentá-lo em combate singular e pressioná-lo pela fome no asilo do sepulcro, então, ainda lhe restará matá-la e matar-se, para que, se ele não puder tê-la, ninguém mais a possua, e para que essas mortes pesem como dor inextinguível sobre Teônoe e como opróbrio sobre o morto que falhou na incumbência de custódia e devolução da esposa (Hel. 975-90). Admitidos como autênticos os versos Hel. 991-995, Menelau, ao mencionar a eventual coerção de matar Helena, surpreende-se com as próprias lágrimas, contém-se e aceita como glorioso o destino de morrer em luta (Hel. 991-993), mas conclui com a peroração de que Teônoe se deixe persuadir para que ela mesma seja justa e ele próprio tenha a sua esposa (Hel. 994-995).

Teônoe, em nome da Justiça, acolhe a súplica, prometendo manter silêncio, e aconselha o casal a suplicar às Deusas Cípris e Hera por salvação e regresso à pátria (Hel. 9981029).

Na sexta cena (Hel. 1032-1106) do segundo episódio, outra vez a sós, diante da ameaça mortal do rei, contando apenas com o silêncio solidário da profetisa, Helena pede a Menelau que planejem a fuga (Hel. 1032-1034). Na disticomitia (Hel. 1035-1084), num primeiro momento Menelau tem a iniciativa, mas as suas propostas, a de fugirem num carro e a de ocultar-se no palácio e matar o rei, não resistem ao exame, e Helena exorta-o a ouvi-la, apesar de ser mulher, se disser algo sábio (Hel. 1048), e toma a iniciativa na elaboração do plano, que recorre à astúcia e joga com as aparências e com a mentira, para ludibriarem o rei e servirem-se dele na consecução da fuga. O aspecto ominoso do plano - dar ao rei a falsa notícia da morte de Menelau com a encenação de luto - suscita em Menelau, além da anuência e do interesse, um comentário irônico: «há nessa palavra alguma velharia» ( Hel. 1056). 
Admitindo que haja aí uma referência a Coéforas de Ésquilo e a Electra de Sófocles, William Allan ${ }^{3}$, a meu ver, com razão, aponta nessa ironia do comentário de Menelau um recurso intertextual que ressalta tanto a originalidade do tratamento euripidiano desse tema tradicional quanto a habilidade e complexidade do plano de Helena.

Concluída a elaboração do plano, Helena propõe a Menelau que permaneça no sepulcro, cujo asilo, juntamente com sua espada, o defenderia de eventual agressão, enquanto ela cuidaria da encenação do falso luto no interior do palácio; e, conforme instruções de Teônoe, ela faz uma prece a Hera, pedindo novo alento, e outra prece a Afrodite, que lhe permita morrer na pátria (Hel. 1085-1106). Helena não descuida de adequar cada uma de suas preces ao momentâneo favor de uma e ao momentâneo desfavor de outra das Deusas, em cujos âmbitos, momentaneamente conflituosos, ela se move e põe em ação o seu plano.

Após o longo segundo episódio, que reúne o casal no reconhecimento mútuo, no apelo à profetisa e no plano de fuga, o primeiro estásimo (Hel. 1107-1164) se constitui numa ampla contemplação da guerra, seu início e conseqüências no plano humano para ambos os adversários, suas implicações e seu lado misterioso nos imperscrutáveis desígnios divinos.

Este primeiro estásimo, como os outros dois que num ritmo mais acelerado o seguem, se compõe de dois pares de estrofe e antístrofe. A primeira estrofe (Hel. 11071121) tem três partes: na primeira, invoca o rouxinol, cujo mito etiológico está presente em diversas tragédias (a saber: Ésquilo - As Suplicantes 57-72, Agamêmnon 11401149; Sófocles - Electra 107-109, 1076-1077, Ájax 628-630, As Traquínias 963; Eurípides - Hécuba 336-338; Reso 546-550), e cujo nome (aedóna, Hel. 1110) se presta ao jogo com a palavra aoidós («cantor», cf. aoidotátan, Hel. 1109); na segunda, convida o rouxinol cantor a associar-se ao lamento pelos infortúnios de Helena e das mulheres troianas, vítimas da guerra; e na terceira, evoca a viagem marítima de Páris, ao conduzir a lastimável esposa de Lacedemônia a Tróia, seguido de Afrodite, início da terrível guerra. A primeira antístrofe (Hel. 1122-1136) reproduz essa estrutura tripartida: primeiro, deplora os muitos aqueus mortos em combates, as viúvas enlutadas e seus leitos vazios; depois, lastima os mortos no naufrágio provocado por Náuplio, nos recifes Caférides, próximos às costas da Beócia, quando em vingança da morte de seu filho Palamedes acendeu fogueiras noturnas que davam falsas indicações aos navegantes gregos; e por fim, lamenta as errâncias marítimas de Menelau, iludido como Páris com a imagem criada por Hera, ao tentar retornar à pátria.

A segunda estrofe (Hel. 1137-1150) põe em questão a incognoscibilidade dos Deuses e de seus desígnios, causa incompreensível da guerra, de que os homens mortais são agentes e vítimas; os infortúnios e a injusta infâmia de Helena, filha de Zeus, exemplificam a opacidade dos desígnios divinos. A segunda antístrofe (Hel. 1151-1164) deplora a demência e inépcia dos homens que se ufanam de conquistas e glórias guerreiras, cujos frutos são lúgubres dores, míseros infortúnios, morte e ruínas.

Não se pode, contudo, inferir desse estásimo uma intenção anti-belicista ou pacifista, pois na perspectiva do pensamento mítico grego tradicional, a guerra, filha da Deusa

${ }^{3}$ William Allan - Eurípides Helen, Cambridge University, 2008, pp. 260-261 
Noite (cf. Hesíodo, Teogonia, 226-230), é um aspecto divino do mundo, que os mortais - tanto pela sabedoria própria quanto pelo favor divino - podem e devem contornar e evitar, mas de que - no limite - não podem escapar.

O terceiro episódio ( $\mathrm{Hel}$. 1165-1300) contém duas cenas: na primeira cena $(\mathrm{Hel}$. 1165-1185), estão Teoclímeno e serviçais, mudos; embora presente, Menelau lhes passa despercebido; na segunda cena (Hel. 1186-1300), figuram Teoclímeno, Helena e Menelau.

Na primeira cena (Hel. 1165-1185) do terceiro episódio, o rei Teoclímeno retorna da caça e, antes de ordenar aos servos que recolham os cães e as redes ao palácio, saúda o túmulo de seu pai Proteu, apresentando-se como o seu filho, o que supre a falta de anúncio de sua entrada. Tanto a fórmula de saudação (ô khaîre, Hel. 1165) quanto a inusual localização do túmulo diante do palácio distinguem o rei Proteu dos mortos comuns e assinalam o seu caráter heróico ou divino; por outro lado, a saudação e a explicação da localização do túmulo revelam também um forte vínculo de piedade filial com o morto (Hel. 1165-1168). Teoclímeno lamenta não ter punido de morte os maus vigilantes, por ter sabido da presença de um grego, que ele teme lhe possa roubar Helena. Esse temor explica tanto a severidade com que persegue os gregos recém-chegados, quanto o motivo da hostilidade da velha contra Menelau no primeiro episódio (Hel. 1171-1176). Em seguida, Teoclímeno se alarma ao ver vazio o assento no túmulo, supondo que Helena já lhe fora subtraída, e expede ordens que recuperem a esposa de seu desejo (Hel. 11771183), mas suspende as ordens, ao perceber a aproximação de Helena, com trajes negros, cabelos cortados e aparente luto (Hel. 1184-1193).

Na segunda cena (Hel. 1186-1300) do terceiro episódio, o plano de fuga do casal se põe em andamento, no ritmo rápido da esticomitia, primeiro entre Teoclímeno e Helena (Hel. 1195-1249) e depois entre ele e Menelau (Hel. 1250-1277). Nessa esticomitia, o jogo do ludíbrio e a manipulação das aparências conferem às palavras uma duplicidade de sentido, fausta para o casal de ludibriadores, infausta para o rei ludibriado, que dela não se apercebe.

O rei Teoclímeno desconhece a identidade de Menelau, que assim pode passar por um náufrago, companheiro de Menelau, que trouxe a Helena a notícia da morte de seu marido. Quando Helena o aponta como o portador da má notícia e diz: «fosse ele aonde quero que vá!» (Hel. 1021), a frase soa para Teoclímeno infausta como uma maldição enfurecida, e para o casal, fausta como um voto de regresso feliz à pátria.

Toda a situação fica sob essa ambivalência, porque se põe sob dois pontos de vista diversos: o da intenção alegada - ou seja, dar ao supostamente morto Menelau os pretensos funerais no mar - e o da intenção oculta - ou seja, obter os meios da fuga pelo mar.

Submetido ao ludíbrio, Teoclímeno revela não somente respeito pelo fingido luto de Helena, mas ainda generosidade tanto ao oferecer os solicitados bens para as supostas exéquias, quanto ao prometer espontaneamente o resgate do farsante náufrago à Grécia. Se somarmos a esse respeito e a essa generosidade de Teoclímeno a piedade filial manifesta em sua saudação ao túmulo do pai e em suas explicações para a inusitada localização do túmulo, podemos concluir que esse rei respeitoso, generoso e piedoso foi duas vezes vítima da Deusa Afrodite: primeiro, ao ser compelido pelo desejo de Helena a romper o compromisso paterno de restituí-la ao marido e assim agir de modo injusto e 
cruel, e depois ao deixar-se ludibriar pela encenação de luto da sedutora e desejada Helena. Teoclímeno ilustra, pois, a acerba acusação da prece de Helena a Afrodite: «Por que és insaciável de males, / com amores, logros, dolosas invenções, / e sangrentos encantamentos de corpos?» (Hel. 1102-1104).

O segundo estásimo (Hel. 1301-1366), como o primeiro e o terceiro, se compõe de dois pares de estrofe e antístrofe, e também como eles, amplia a visão da ação em curso no drama pela contemplação de suas implicações e de suas interfaces com o divino.

A meu ver, esta ode se prende ao terceiro episódio, imediatamente anterior, por contraposição e contraste, o que os reúne numa unidade antinômica. Enquanto nesse episódio, Helena e Menelau, com uma simulação das exéquias do próprio Menelau, conquistavam os meios de fugir à morte e o regresso à pátria e à vida, essa ode evoca, com o mito de Deméter e da filha, o verdadeiro sentido da morte e a verdadeira dimensão da perda por morte.

A primeira estrofe (Hel.1301-1318) primeiro narra a busca erradia da montês Mãe dos Deuses saudosa da finada filha nefanda (Hel. 1301-1307). A situação descrita e os epítetos «montês» (ourê̂a), atribuído à «Mãe dos Deuses» (Máter... Theôn), e «nefanda» (arrétou), atribuído à «filha» (koúras), desde já refletem e assinalam o sincretismo - comum no período clássico - entre a Deusa frígia Cibele e as gregas Deméter e Réia. Em seguida, a narrativa retrocede ao momento do rapto da filha por Hades, e descreve a tentativa pela Deusa Mãe de impedir a consumação do rapto, com seu carro puxado por leões, ao som de estrondosos címbalos, bem como a mesma tentativa pelas Deusas Ártemis e Atenas, armadas respectivamente com o arco e a lança, e presentes no momento do rapto (cf. Hino Homérico a Deméter 424), e ainda a vigilância de Zeus, anuente com o seu irmão raptor, e cuja decisão era diversa do amoroso desejo materno. Observe-se ainda que címbalos, ou crótalos, são pratos de bronze, instrumentos de percussão comuns aos cultos de Deméter, da Mãe dos Deuses e de Dioniso, com o que um traço de Dioniso está também presente nesta descrição do rapto de Perséfone.

A primeira antístrofe (Hel. 1319-1337) descreve a cessação da busca, frustrada por ser contrária à decisão de Zeus, a intensidade da aflição da Deusa pela perda de sua filha, e as conseqüências de seu luto, para os homens e os Deuses: a infertilidade do solo, a esterilidade das lavouras, a morte dos homens e dos rebanhos, a falta de víveres nas cidades, a supressão dos sacrifícios e das oferendas, e a seca dos mananciais.

A segunda estrofe (Hel. 1338-1352) relata o recurso de Zeus ante a aniquiladora cólera da Deusa, a que Zeus então se refere com o hipocorístico «Deo»: confiante no poder curativo do canto e da dança, ele convoca Graças e Musas para apaziguá-la com os alaridos e os hinos corais. Neste ponto, esta ode difere de outras versões do mesmo mitologema: é toque inaugural de Afrodite - referida, então, como «Cípris, a mais bela das Deusas» - nos címbalos e nos tambores que desperta, na Deusa enlutada, o riso e a aceitação prazerosa do gravíssono aulo, que doravante se incorpora ao seu culto.

A meu ver, esta participação decisiva de Afrodite no abrandamento do luto e da cólera da Deusa é relevante como um ponto comum de coincidência na unidade antinômica, feita de contraposição e contraste, entre esta ode e o episódio anterior. Na encenação das falsas exéquias com que Helena e Menelau resgatam a própria vida, age não nomeada a Deusa Afrodite, pois é seduzido pela beleza de Helena que Teoclímeno se deixa persuadir, permitindo assim que Helena resgate a sua própria vida e a de seu marido. 
Na segunda antístrofe (Hel. 1353-1366), os editores até hoje consideram desesperadamente corruptos os dois primeiros e os três últimos versos; no entanto, poderíamos encontrar o sentido geral desses versos iniciais e finais na perspectiva aberta pela leitura que propomos da unidade antinômica entre o terceiro episódio e o segundo estásimo.

O verso inicial hôn ou thémis oúth' hósia (Hel. 1353) traduzimos «sem lei nem liceidade», deixando implícito o pronome hôn - desnecessário à clareza do verso traduzido, já que aparentemente se refere aos címbalos, tambores e aulo descritos na estrofe anterior e tomados como metonímia do culto à Deusa sob cuja referência se põe toda a ode.

O verso seguinte epýrosas en thalámois (Hel. 1354) traduzimos «acesa a lareira em casa» - entendendo a ação, descrita pelo verbo epýrosas (que literalmente diz «acendeste o fogo»), de acender a lareira, como uma metáfora do regresso de Helena ao seu lar e à vida doméstica. Esse regresso, conquistado por Helena e Menelau mediante a simulação das exéquias do próprio Menelau, necessariamente desconhece a lei e a liceidade do culto de Deméter e de sua filha, culto fundado no sentido divino do traspasse e do falecimento.

Se essa leitura está correta, o que se lê nesses dois versos iniciais é reiterado nos versos seguintes: «tens a cólera da grande Mãe, / ó filha, por não observar / os sacrifícios à Deusa» (Hel.1355-1357), entendendo-se que «observar / os sacrifícios à Deusa» significa o reconhecimento e reverência ante o sentido divino do transpasse e do falecimento bem como das exéquias.

Essa ausência de lei e de liceidade - em que se move a simulação das próprias exéquias mediante as quais o casal recobra a própria vida - confronta não só a figura divina da «grande Mãe» em que confundem as Deusas Réia, Deméter e Cibele, mas confronta também Dioniso. Por que Dioniso? Nos limites desta ode, a resposta a essa questão parece estar na assinalada presença e importância de instrumentos comuns aos cultos da grande Mãe e de Dioniso, sincretismo também documentado em As Bacas de Eurípides.

Em seguida à apóstrofe e advertência a Helena por sua não observação dos sacrifícios à Deusa, as insígnias cultuais de Dioniso e as festas noturnas da Deusa lado a lado se nomeiam como detentores de grande poder (Hel. 1358-1365), justamente os poderes que Helena confronta com suas falsas e salvadoras exéquias.

Suposto que essas festas da Deusa fossem celebradas em noites de plenilúnio, a visão da Lua não somente dominava o tempo de duração das festas, mas ainda, em sua fase minguante, a Lua se podia contemplar «por dias» (ámasin, Hel. 1366), já terminadas as festas.

A Lua, pois, que paira acima e além das festas noturnas, por poderosas que estas sejam e se reconheçam, seria, pois o símile da beleza de Helena e dos atributos de Afrodite, mediante os quais Helena, por fim, pode resgatar a sua própria vida e a de seu marido.

Nesta seqüência, a meu ver, os três últimos versos deste estásimo diriam: «Bem por dias / Lua as supera, / forma só ufanavas» (Hel. 1366-1368).

Helena, que reiteradas vezes deplorou sua beleza como causa de seu infortúnio (Hel. 27, 236-237, 261-265, 303-305, 375-385), em verdade, quando pôs o seu plano em ação, ufanava sua formosura, que sobre o rei exerce um irresistível poder persuasório análogo, nesta ode, ao poder de Cípris sobre a cólera de Deméter. Ou, ainda, retomando os três últimos versos desta ode, pode-se dizer que esse poder da formosura, por conduzir Helena e seu marido além do presente perigo, é análogo à Lua, que no plenilúnio do- 
mina a paisagem e, por dias, supera as reconhecidamente poderosas festas noturnas da Deusa Mãe.

O quarto episódio (Hel. 1369-1450) contém duas cenas: na primeira cena $(\mathrm{Hel}$. 1369-1389), temos Helena; na segunda (Hel. 1390-1450), Teoclímeno, Helena, Menelau e servos (personagens mudas).

Na primeira cena, Helena, só, dirigindo-se ao coro, narra os acontecimentos do interior do palácio, ressaltando o perigo à espreita e o andamento do plano: Teônoe, interrogada pelo irmão, mente que Menelau está morto, ocultando assim sua presença entre eles; banhado da salmoura marinha, Menelau veste as armas, que deve conduzir ao pretenso funeral, como para triunfar dos bárbaros, uma vez no navio. Por fim, Helena anuncia Teoclímeno, salientando a sua iludida pretensão de núpcias, e pedindo o silêncio cúmplice ao coro com a promessa de, quando salvos, resgatá-lo.

Na segunda cena, Teoclímeno ordena aos servos que transportem as oferendas fúnebres como manda o forasteiro e, mais uma vez, tenta persuadir Helena de que permaneça em terra com ele enquanto outros façam por ela os funerais, alegando o temor de que as saudades do morto a precipitem às ondas.

Helena, num discurso cheio de duplos sentidos, dos quais Teoclímeno só pode perceber o que lhe afaga o desejo, convence-o a deixá-la tomar parte dos funerais, e pede-lhe o navio em que fazê-lo. Na breve esticomitia, também eivada da mesma duplicidade de sentido e da mesma cegueira do interlocutor, Helena obtém do rei que o comando do navio fique com o forasteiro grego que preside as exéquias.

Completamente seduzido e iludido, Teoclímeno permite que Helena faça as falsas exéquias do marido pretensamente morto, e ordena aos servos que preparem as suas núpcias com Helena. Por fim, Menelau faz uma prece a Zeus e aos Deuses, que lhe dêem boa sorte. Como o seu anterior pedido de proteção a Teônoe, essa prece tem mais o caráter de uma injunção e de um desafio que o de uma súplica.

O terceiro e último estásimo (Hel. 1451-1511) abre, com votos favoráveis e com preces, a perspectiva do regresso e reintegração do casal à vida na pátria. A primeira estrofe (Hel. 1451-1464) invoca o navio fenício como o corifeu de um coro de golfinhos e descreve a Deusa «Calmaria» (Galáneia, Hel. 1457), «filha de Mar» (Póntou thygáter, Hel. 1456), a instruir os marinheiros na consecução de feliz travessia. A primeira antístrofe (Hel. 1465-1477) antevê a chegada de Helena ao templo de Palas - donde fora raptada e transportada por Hermes ao Egito, - o reencontro com as cunhadas viúvas dos Dióscoros, filhas de Leucipo, a reintegração nos coros ou nas celebrações de Jacinto, instituídas por Apolo pesaroso da involuntária morte infligida a seu amado, e ainda o reencontro com a filha Hermione. Na segunda estrofe (Hel, 1478-1494), o coro deseja juntarse aos grous que migram da Líbia e guiados pelo mais velho sobrevoam o Egito, e convida-os a pousarem junto ao rio Eurotas e anunciarem a Esparta a conquista de Tróia por Menelau e seu retorno ao lar. A segunda antístrofe (Hel. 1495-1511) é uma prece aos Dióscoros para que escoltem a viagem marítima de Helena e defendam a irmã contra a infundada infâmia de núpcias bárbaras, uma vez que ela não foi jamais a Tróia.

O êxodo (Hel. 1512-1692) contém duas cenas, distinguidas pela epifania dos Dióscoros na segunda.

Na primeira cena (Hel. 1512-1641), o jogo de ilusões que envolvia Teoclímeno se desfaz. Um dos servos incumbidos das exéquias marinhas de Menelau retorna do mar, 
com a notícia de que «descobrimos o pior em casa» (tà kákist' en dómois heurékamen, Hel. 1512), pois o que tem a dizer inverte as expectativas de núpcias no palácio real: o rei Teoclímeno deve cortejar outra mulher, Helena deixou o país, transportada em navio do rei por Menelau, que viera ele mesmo ao palácio anunciar a sua própria morte. Este será, nesta tragédia, o segundo relato de mensageiro, depois do relato da ascensão da imagem celeste de Helena, feito pelo velho servo a Menelau. Poderíamos, para efeito de nossa análise, considerar que este segundo relato se articula em sete segmentos, a saber:

1) - A preparação do navio (Hel. 1526-1536): com ardiloso pranto Helena caminha para o mar, ao lado de Menelau, ainda incógnito; os servos retiram do estaleiro um navio novo e fazem os ajustes finais.

2) - O inesperado acréscimo da tripulação (Hel. 1537-1553): náufragos gregos companheiros de Menelau - vindos à praia, e convidados a participar do cenotáfio marinho, embarcam com fingidas lágrimas e oferendas, e por serem muitos, pareceram suspeitos aos egípcios, que se calaram, porque as ordens de Teoclímeno davam o comando do navio ao forasteiro.

3) - O inusitado embarque do touro sacrificatório (Hel. 1554-1568): a resistência do touro a embarcar - ominosa, porque a vítima sacrificial devia dar sinais de anuência ao sacrifício - quebra-se com a ordem de que o embarquem à maneira grega, carregado às costas dos jovens; mas o corcel embarca persuadido por afagos de Menelau.

4) - O embarque de Helena e dos gregos (Hel. 1569-1576): Helena se senta no banco do meio do navio, perto do marido, e os gregos se distribuem de ambos os lados, com facas ocultas sob as vestes.

5) - A reveladora prece do sacrifício (Hel. 1577-1588): já não muito longe da terra, interpelado pelo piloto, Menelau, sem mencionar o morto, imola o touro, com a reveladora prece de que Posídon e Nereidas lhes dêem, a ele e à sua esposa, salvo retorno às praias de Náuplia, e o jorro de sangue atinge o mar, sinal de que os Deuses aceitaram o sacrifício.

6) - A contraposta conclamação à luta (Hel. 1589-1599): denunciado o seu dolo, Menelau conclama os gregos ao massacre e despejo dos bárbaros ao mar, e o contramestre instiga que se defendam com bancos partidos e com remos.

7) - A vitória dos gregos e a fuga do mensageiro (Hel. 1600-1618): travando-se o combate de remos contra facas, Helena na popa exorta os gregos, e Menelau com armas os acode, onde precisassem, até livrar o navio dos bárbaros, quando dá ao piloto ordens de dirigir o navio à Grécia, e içam-se as velas, com vento propício. Após escapar da morte, o mensageiro se lança ao mar, e resgatado por um pescador, pode anunciar esses fatos ao rei.

Concluído o relato, o corifeu simula surpresa diante da fuga bem sucedida (Hel. 1619-1620).

Sentindo-se duplamente atingido, ludibriado por mulher e privado das núpcias, o rei reconhece a impossibilidade de capturar os fugitivos, e volta a sua fúria contra a adivinha, que considera traidora por ter-lhe sonegado a presença de Menelau (Hel. 1621-1626).

Intervém, então, o corifeu, que intercepta os passos do rei e defende a atitude de Teônoe como piedosa e justa, disposto a morrer por ela. Numa breve e contundente esticomitia (ou melhor, hemisticomitia, pois cada personagem diz parte de um mesmo verso), o corifeu refuta todos os motivos e todo direito alegados de Teoclímeno para matar 
Teônoe e por fim resiste mesmo à ameaça de morte do rei contra ele (Hel. 1627-1641). $\mathrm{Na}$ atribuição dessas falas ao corifeu, seguimos A. M. Dale (Eurípides - Helen, Bristol Classical, 2004, p. 165-166) e William Allan (Eurípides - Helen, Cambridge University, 2008, p. 338), que coincidem nos argumentos e contra-argumentos para identificar nestes versos como o corifeu o interlocutor de Teoclímeno. Ambos, Dale e Allan, argumentam que somente o corifeu, presente todo o tempo e solidário com as razões de Teônoe para preservar Menelau, teria condições de interceptar o rei e contrapor-se a ele, e não um inesperado e não anunciado servo anônimo, surgido não se sabe donde; e ambos eles contra-argumentam que as formas masculinas - o singular doûlos ón («sendo servo», Hel. 1630) e o plural hemôn hekónton («com nossa anuência», Hel. 1640) - têm um valor generalizante, e como tais podem ser aplicados ao corifeu, por falar de si mesmo em nome do coro, ou por ser referido em sua condição inespecífica de servo em geral.

A epifania final dos Dióscoros pacifica o rei e traz-lhe a aceitação dos fatos. Para compreendermos que sentido poderia ter no teatro de Dioniso esse recurso do Deus ex machina, presente na maioria das tragédias supérstites de Eurípides, é necessário que nos atenhamos à noção mítica grega de Theós («Deus(es)») como o(s) aspecto(s) fundamental(is) do mundo, e à noção mítica grega de verdade como um dos aspectos fundamentais do mundo, i.e. como uma revelação divina. Esse recurso cênico do Deus ex machina corresponderia à percepção compartilhada de uma verdade transcendente, que ultrapassa os limites habituais dos homens e revela um horizonte extraordinariamente mais amplo do qual se descortinam os desígnios dos Deuses.

A aparição dos Dióscoros se justifica pela proximidade fraterna entre eles e Helena, e eles mesmos se mostram ao rei e ao coro como um paradigma divino da aceitação das injunções divinas. A fala que dirigem ao rei (Hel. 1642-1661) está centrada na noção e no vocabulário da injunção (ou gàr peproménois, «não fadadas», Hel. 1646; ekhrén, «era preciso», Hel. 1651; dề, «deve», Hel. 1654; peproménou, «fatalidade», Hel. 1660) - tanto a injunção divina, a que o rei deve submeter-se, quanto a que se impõe aos Dióscoros mesmos, dada a hierarquia divina, pela qual os desígnios divinos coincidem com a fatalidade e na qual os Deuses e os mortais encontram o que lhes cabe e o que lhes compete.

A fala que dirigem à irmã, Helena (Hel.1662-1679), descreve as compensações divinas para as longas e cruéis misérias do casal, o que não deixa de constituir uma teodicéia, uma reparação divina pelos sofrimentos aparentemente indevidos e infundados, decorrentes dos desígnios divinos.

A verdade como revelação divina produz compreensão e acolhimento nos mortais a quem se revela; o conhecimento dos desígnios divinos demanda e opera a transmutação do ser de quem os conhece, instaurando similitude entre o sujeito e o objeto desse conhecimento. O rei Teoclímeno, interpelado pelos Dióscoros, realiza o prenúncio de seu próprio nome (Theoklýmenos, «o que ouve os Deuses»), supera a perda e o ressentimento, e reconhece a justiça de Teónoe e a integridade moral de Helena.

As palavras finais do coro, comuns a Alceste, Andrômaca, Bacas e, com variação da primeira linha, a Medeia, resumem a compreensão, que se pode ter, de um ponto de vista apenas humano, do curso dos acontecimentos, cujos agentes são mortais e cujos sujeitos são os Deuses. 
BiBLIOGRAFÍA CONSULTADA:

Allan, William (2008): Eurípides Helen, Cambridge University.

CAssin, Barbara (1990): Ensaios Sofísticos. Tradução de Ana Lúcia de Oliveira e Lúcia Cláudia Leão. São Paulo, Siciliano.

Dale, A.M. (2004): Euripides Helen, Bristol Classical, p. 126.

Diggle, J. (1998): Euripidis Fabulae, t. III, edidit, Oxford, Classical Texts.

DunN, Francis M. (1996): Tragedy s End. Closure and Innovation in Euripidean Drama. Oxford University Press,.

Kovacs, David (2002): Euripides Helen Phoenician Women Orestes, vol. V, edited and translated by, Harvard University, Massachussetts,.

Kovacs, David (2003): Euripidea Tertia. Brill, Leiden.

LloYd, Michael (1992): The Agon in Euripides, Clarendon Press Oxford.

LóPEz FÉREZ, Juan Antonio (2004): «Aquiles en Eurípides», in Juan Antonio López Férez (ed.) La tragedia griega en sus textos. Forma (lengua, estilo, métrica, crítica textual) y contenido (pensamiento, mitos intertextualidade). Madrid,.Ediciones Clásicas, p.197-220.

MicheLIN Ann Norris (1987): Euripides and the Tragic Tradition. Wisconsin, The University of Wisconsin Press.

Sourvinou-Inwood, Christiane (2003): Tragedy and Athenian Religion. London, Lexington Book. 
